\title{
Transaction Cost Theory, Political Theory and Resource Dependency Theory in The Light of Unconventional Aspect
}

\author{
Sheila Nu Nu Htay ${ }^{1}$, Syed Ahmed Salman ${ }^{2}$ \\ ${ }^{I}$ Assistant Professor and PhD. Programme coordinator at Institute of Islamic Banking and Finance, \\ International Islamic University Malaysia. \\ ${ }^{2}$ PhD. Candidate at Institute of Islamic Banking and Finance, International Islamic University Malaysia.
}

\begin{abstract}
Islam as a comprehensive religion, it molds our way of life comprehensively from the religious activities to the business activities. Muslims are required to abide the Islamic teachings in their private lives as well as dealing with public. When the business dealings are examined, the top corporate players monitor the management of the company and these players are in turn observed the best corporate governance practices and guidelines issued by the respective regulators. From the conventional perspective, these guidelines are developed based on the theories developed by the prior researchers using their rational thinking and learning from the past experiences. In Islam, it is believed that human being has limited knowledge and thus, their theories founded on rational thinking might not be comprehensive and valid unless it combines with the revealed knowledge. Thus, the purpose of this paper is to examine whether the prevailing corporate governance theories such as transaction cost theory, political theory and resource dependency theory are in line with Shari'ah. It has been found out that none of them are completely in line with Islamic teachings. Thus, this paper suggests the regulators which allow the activities of Islamic finance should revisit their existing conventional corporate governance principles to ensure that they are in line with MaqasidShari'ah and applicable to the needs of the Islamic finance industry.
\end{abstract}

Keywords:Corporate governance theory, political theory, resource dependency theory, Shari'ah and Transaction cost theory.

Submitted Date 22 June 2013

Accepted Date: 27 June 2013

\section{Introduction}

The important role of corporate governance has been widely acknowledged by the investors and regulators, especially due to the financial crisis. The first corporate governance guideline is introduced Cadbury Report in United Kingdom in 1992 and currently, most of the developed and developing countries have introduced the guidelines on best practices of corporate governance. Currently, almost 100 countries have introduced these guidelinesand more tighten guidelines are implemented to monitor the corporate governance players.In addition, international organizations and associations such as Organization for Economic Co-operation and Development (OECD) and Common Wealth Association have provided the corporate governance guidelines. This shows that how the corporate governance plays a significant role for the success of the company[1].

With the emerge of Islamic finance industry, corporate governance still has an influential power on the performance of the industry. The growth of Islamic banking industry is not only penetrating into the Muslim countries but also into the non-Muslim countries. However, the current conventional corporate governance guidelines are prepared based on the theories which are the products of human reasoning, not the religious or spiritual guidance. Due to that, if the prevailing corporate governance theories are not in line with unconventional aspect (shariah) and the guidelines based on these theories are followed by the Islamic institutions, the objective will be undermined. Thus, we feel that it is necessary to examine whether the theories as sources of corporate governance guidelines are in line with shariah. Among the corporate governance theories, transaction cost theory, political theory and resource dependency theory are focused in this paper.

The rest of this paper is organized as follows. The second section discusses on the conventional corporate governance theories, transaction cost theory, political theory and resource dependency theory whereas next section discusses on corporate governance in Islam. Section four talks about these said theories in Islamic perspective and last section concludes. 


\subsection{Transaction Cost Theory}

\section{Corporate Governance Theories}

One of the prevailing economic-based theories of organizational corporate governance is the transaction cost theory. According to Coase [2], its origin can be traced back to the 1930s. However, the idea of transaction costs is recognized as a useful analytical tool in the 1970s through works of several authors, for instance, Oliver Williamson. The transaction cost theory states that a firm as a sum of contracts put in practice in order to organize and regulate transactions serves for accomplishing contractual relations [3]. Its main concern is in carrying out economic transactions based on the most efficient governance structure. Transaction costs refer to explicit fees associated with a transaction as well as implicit fees of monitoring and controlling a transaction. Transaction cost includes the costs of information, search, negotiation in addition to contracting and enforcement. The economic implication is decision-makers have to weigh costs associated with performing an activity in-house against that of outsourcing it to the market. Thus, if the transaction cost of using the market is higher, the transaction should be executed by the firm (in-sourcing). In addition, if they choose to execute a transaction through the market, they have to determine the most appropriate contract to use [2].

With regard to the choice of governance structure by decision-makers, human and environmental factors influences the decision makers attributed. Human factors include bounded rationality and opportunism. Bounded rationality comes from limited capacity of shareholders and managers to process all the available information and consider every possible outcome associated with any transaction. This exposes the contracting parties to some level of risk, for instance, employees or vendors may take advantage of the owners. In order to prevent such an outcome, owners may incur costs related to gathering such information. Meanwhile opportunism is an assumption that human behavior is 'self-interest seeking with guile'. This means that principals and agents have different goals and will pursue their own self-interest. For example, problems may arise when agents do not deliver as promised (moral hazard) or misrepresent themselves (adverse selection)[4].

Environmental factors consist of information asymmetry and asset specificity. Information asymmetry occurs when information related to exchanges or transactions is not evenly distributed. For example, the principal (shareholder) does not possess certain information pertaining to the agent's (manager) behavior or shortcomings and additional costs are incurred to obtain such information through various governance mechanisms. Asset specification refers to assets that are very specific and fixed and hence reducing flexibility in investment decisions. These factors have implications on how the firm interacts with its employees as well as other firms. As suggested by Williamson [5, 6], firms can choose from three generic governance structures namely the market, hierarchy (vertical integration) and hybrid of both. For example, should there be higher uncertainty from information asymmetry and an increase in asset specificity, the risk of opportunism will rise in decision-makers. It can be summed that the transaction cost theory seeks the best governance structure that would control the agents' opportunistic behavior in pursuit of profit maximization for their shareholders.

\subsection{POLITICAL THEORY}

Pound [7] defines the political theory as an approach where "active investors seek to change corporate policy by developing voting support from dispersed shareholders, rather than by simply purchasing voting power or control". A governance structure based on politics is more flexible than the one based on finance because "it can address specific problems at a corporation without imposing changes in control, changes in management, and the enormous transactions costs attendant to them".

The political theory suggests that the both the government and corporate sector determine the delegation of power and authority to managers of a particular organization and their relationship towards other stakeholders. This means the ability of corporate stakeholders to influence decision-making at a micro level is subject to the framework at a macro level and the framework in turn is affected by a particular jurisdiction in which they are operating[8]. However, the term 'political' is not limited to the role of governments and it can also refer to a non-market entity. Interesting enough, politics can also account for the existence of different corporate governance systems globally. Corporate governance systems can be classified into two main categories namely market-oriented system and bank-oriented system [9, 10]. The market-oriented system, also known as the Anglo-Saxon model, is adopted in the US and United Kingdom (UK). Corporations are publicly listed in stock markets with dispersed ownership (small interest). This means shareholders' ability to monitor and control the management is reduced resulting in conflicts between both sides. Due to their reliance on capital markets, threats of hostile takeovers become the means to gain control. In this case the interests of other stakeholders such as employees and suppliers are outranked to that of shareholders. According to Roe [11], policies are associated with dispersed ownership is "a product of political intervention" that aims to achieve economic efficiency by limiting the influence banks have on corporations.

In contrast, the bank-oriented system or Continental-European model involves concentrated ownership. Adopted in most continental European countries such as Germany and Japan, restricted voting powers 
undermine the possibility of hostile takeovers. There is less reliance on capital markets or outside investors and more on financial institutions or inside investors. This way, interests of all stakeholders will be considered on top of that of shareholders. Roe [11] explains that the choice of corporate governance models in different countries "interact deeply with a nation's politics". Political forces in the form of party systems, political orientations of governments and coalition and ideologies are factors that determine the degree of shareholder diffusion as well as the relationships among managers and all stakeholders. He further argues that in Germany, for example, where social democracy is strong, shareholder rights are weak and social diffusion is low. This is because social democracy provides all stakeholders with the ability to pursue their individual interests that comes in the form of job security for employees and regional or national development controlled by the government.

\subsection{Resource Dependency Theory}

Resource dependency theory focuses on the role of board directors in providing access to resources needed by the firm [12]. The resources can be derived from insiders, experts, support specialists and community influential. All this group of directors provides specific resources based on their expertise in specific area. The resources may be in the form of legal advice, skills and information.

Basically, firms use this theory in strategic decision-making. The directors will ensure the essential resources are provided and secured to an organization by having a networking with the external environment. The resources provision is important as it determines and encourages organizational functioning as well as firm's performance and survival. This theory emphasizes that the resources should be managed effectively and efficiently since it becomes a benchmark in determining the success of an organization[13].

On the other hand, the resources should not be in term of directors' expertise only, but the ability to have contact with outside network should be concerned as it gives chances to the company to access to new markets, sources of finance and reputation benefits. Besides that, the diversity of corporate board members is the vital element whereby it enables the firm to broader corporate networks and improves financial performance[14].

Firms also use the theory to minimize increasing dependency and uncertainty by altering organizational interdependence. In order to reduce the dependency level, firms engages in mergers and acquisitions. $[15,16]$ asserts that most organizations prefer to involve in mergers and acquisitions because it helps them to reduce competition and enable them to exchange operations and expertise. Thus, firms are able to meet each other's objectives and goals in collective manner.

However, problem arises when the firms are involving in this mergers and acquisitions. One of the problems is power imbalance. Basically, the more powerful firm views the dependent firm as ineffective. Hence, the powerful firm tends to exploit the resources for their own benefits and advantages. Consequently, the satisfaction level among the dependent firm will decrease and it leads to a greater hostility and dissatisfaction with the relationship [17].

\section{Corporate Governance In Islam}

Before discussing whether the theories discussed are in line with Shari'ah, it is important to understand what corporate governance means in Islam. Under the conventional governance model, the debate is largely on agency issues whereas the Islamic view is one of stewardship or trusteeship. Wealth belongs to Allah and everyone,regardless of the manager, shareholder or the stakeholder;he isthe trustee of this wealth. This makes Islamic concept of governance fundamentally different from its conventional counterpart[18].

\subsection{ISLAMIC WORLDVIEW}

Worldview refers to 'the way that one sees and understands world events, especially in relation to their religious or political beliefs and ideas ${ }^{1}$ and the Islamic worldview is fundamentally different from the Western version. According to Al-Attas[19], Islamic worldview is reflected as "vision of reality and truth" (ra'yat alIslam li al-wujud). As such, Muslims are concerned with this world and the Hereafter or Day of Judgment.

God created man with the sole purpose of managing this world as a vicegerent (khilafah). Equipped with mind (aql) and intuition, man has the capacity to think independently as well as distinguish between good and evil. At the same time,man as a servant (Abd) of Allah, he is not self-governing and answerable to God. This explains why Islamic concept of management is so dissimilar compared to others and it has serious implications in deciding whether the conventional corporate governance theories are acceptable in Islam.

\subsection{SHURA AND HISBAH}

${ }^{1}$ Based on definition by Macmillan Dictionary 
Islamic corporate governance in relation to decision-making aspect comprises of three different Islamic institutions namely shura, hisbah and Shari'ah supervisory board.The concept of Shura (consultation) has been prescribed in the Holy Quran, 42:38; those who hearken to their Lord, and establish regular Prayer; who (conduct) their affairs by mutual consultation; who spend out of what we bestow on them for Sustenance.

Shura simply means mutual consultation and consensus. This concept involves the use of consultation and selection of representatives to discuss and formulate state policy [20]. Under this concept, no individual should influence the decision and it should be done by the mutual consent among the directors. The institution of shura can be seen as a good example of political democracy. This concept was applied during the Prophet's time, particularly after Hijrah as he set up all the necessary principles of good governance[21].

Hisbah is another important social institution that has been practiced by the Muslim society since the early period of Islam. The concept of hisbah was not explicitly mentioned in the Al-Quran but the essence can be derived from it and can be found from many verses in the Al-Quran. Hisbah refers to a socio-economic institution that promotes good and forbids vice.

Hisbah plays a significant role in the Muslim world because through this institution, the state can enforced socio-economic control on trade and economic practices [20]. The establishment of this institution can be traced back to the Prophet's life. After hijrah, he established foundations of a new Islamic order. In order to do that, the Prophet signed the treaty called the Constitution of Madinah. The Prophet then created an autonomous market where Muslim community can participate in line with the Shari'ah principles. This is where the institution of hisbahcomes into picture to ensure the right economic and commercial activities are practiced in conformity with the Shari'ah. Good governance can be realized if the hisbahprinciples are fully implemented. Lastly is the establishment of Shari'ah supervisory board and religious audit. It also required in the context of Islamic corporate governance in order to guarantee that all operations contracts and procedures in accordance with rules of Shari'ah. The function of this institution should cover three main areas namely provision of advice monitoring performance and the audit of Islamic tax [21].

\subsection{Business Ethics And Justice}

Business ethics is "a discipline that addresses the moral features of any commercial activity"2. In business transactions from an Islamic perspective, there are two types of codes introduced to regulate consumption, production and distribution namely 'halal' (allowed and praise-worthy) and 'haram' (prohibited and blame-worthy) codes. In addition, business virtues were also brought into play such as iqtisad (moderation), adl (justice), ihsan (kindness), amanah (honesty), infaq (meeting social obligations) and sabr (patience) as well as negative values identified as zulm (tyranny), bukhl (miserliness), hirs (greed), iktinaz (hoarding) and israf(extravagance) [22].

Justice is an essential element of the Islamic faith and the religion seeks to eradicate all traces of injustice, exploitation and oppression (zulm) from human society. The Islamic banking systemshould be made to contribute richly to the achievement of major socio-economic goals such as an equitable distribution of income and wealth [23].

Moreover, justice is one of the main objectives of shariah and what the religion of Islam wants for human being. In Arabic, adl and qist mean 'to act justly' and these terms have been used in the Holy Quran, including An-Nisa 4:135, A'raf 7:181, Al-Hadid57:25 and as provided below, An-Nahl 16:90;Allah commands justice, the doing of good and giving to kith and kin, and He forbids all indecent deeds, and evil and rebellion: He instructs you that ye may receive admonition.

The verses are clear on justice as fairness, justice as non-discrimination and justice as equity in order to ensure balance and harmony.

\subsection{Transparency, Accountability And Disclosure}

In relation to corporate governance, Islam takes it one step further with an objective in mind that is to ensure 'fairness' to all stakeholders (justice). This can be accomplished through greater accountability and transparency [24].

Hence it could be assumed that transparency, accountability and disclosure are three important components of Islamic corporate governance. There is an increasing awareness on the need to protect the rights of all stakeholders. Even though the term 'corporate governance' is relatively new, the concept is not foreign to Islam. For instance, the Holy Quran has provided a detailed account on processes involved when carrying out a transaction, as found in Sura Al-Baqarah verses 282-283;O you who believe! When you contract a debt for a fixed period, write it down. Let a scribe write it down in justice between you. Let not the scribe refuses to write as Allah has taught him, so let him write. Let him (the debtor) who incurs the liability dictate, and he must fear Allah, his Lord, and diminish not anything of what he owes then if one of you entrust the other, let the one who

${ }^{2}$ Based on definition by Stanford Encyclopedia of Philosophy 
is entrusted discharge his trust (faithfully) and let him be afraid of Allah, his Lord. And conceal not the evidence for he, who hides it, surely his heart is sinful. And Allah is All-Knower of what you do.

These verses explain the importance of proper record-keeping (through contracts) so no party involved suffers unfairness. It is clear that Islam advocates the need for transparency and disclosure in all business dealings. This is just and important concept in contemporary (conventional) corporate governance as well[25]. Other than transparency, another important aspect of corporate governance is accountability. The term refers to 'an obligation or willingness to accept responsibility or to answer for one's actions ${ }^{3}$. The Prophet (S.A.W) was reported in one Hadith as saying"Each one of you is a guardian, and each guardian is accountable to everything under his care".

Applying His words in today's context, those involved in business transactions are responsible for their actions. ShahulHameed[26] defines "Islamic" accountability as that of a dual nature because the primary accountability is towards God where man is a khalifah (trustee), entrusted with resources. The secondary accountability involves a contractual relationship and it could be between an owner (investor) with a manager or employees and management.

In the Islamic economy and political system, Shari'ah is the essential guiding force as it encompasses all aspects of human life. Thus, there is no exception in the corporate governance players not to follow. All of us will be ultimately accountable to Allah and all our deeds will be answerable to Allah, as stated in the Holy Quran, 2:284.To Allah belongs whatever is in the Heavens and whatever is in the Earth. Whether you show what is within yourselves or conceal it, Allah will bring you to account for it.

\section{Transaction Cost Theory, Political Theory And Resource Dependency Theory: An Islamic Perspective} 4.1 Transaction Cost Theory: An Islamic Perceptive

According to the transaction cost theory, decision-making should be based on the most cost-effective option. This seems to be in line with Shari'ah as it adopts the principle of moderation. The term that means "avoiding extremes of behavior or expression and observing reasonable limits" ${ }^{4}$ has always been considered a praiseworthy quality from an Islamic perspective. Even with regards to acts of worship, Muslims are taught to be reasonable as evidenced in the Holy Quran, 2:143; Thus, have We made of you an Ummah justly balance, that you might be witnesses over the nations, and the Messenger a witness over yourselves

In addition, there are evidences from Hadiths that the Prophet (s.a.w) outlined the defining qualities of moderation. For example, when some companions of God's Messenger resolved to engage in worship by praying all night, fasting non-stop or not marry and avoid relations with women, the Prophet said; "I swear by God that I fear God and realize my responsibilities to Him more than you, but this is my way: I fast sometimes and sometimes I do not fast, I pray during the night and sleep as well; and marry women. Anyone who does not like my way has no relation with me".

Moderation is an Islamic principle and it needs to be observed in every aspect of life. It is not confined to acts of worship. Mankind is provided with the golden rule of moderation between spending lavishly and holding back our wealth due to stinginess as seen in the Holy Quran, 17:29;And let not your hand be tied (like a miser) to your neck, nor stretch it forth to its utmost reach (like a spendthrift), so that you become blameworthy and in severe poverty

Therefore, at a superficial level, transaction cost theory seems to be in accordance with Shari'ah. However, upon a deeper understanding of the theory, we conclude that it is not in line with Shari'ah principles as the ultimate objective of choosing the most cost-effective option is profit maximization without spiritual consideration.

It is noteworthy to point out that Islam recognizes the human need to pursue self-interest and profit maximization in commercial transactions. After all, it can be argued that believers can maximize self-interest within the boundary of Shari'ah. According to Hasan[27], there is a distinction between self-interest and selfishness where the former can be pursued within the ambit of morality while the latter would always violate it. One way to distinguish the two is by considering one's intentions. In Islam, even the pursuit of self-interest must be accompanied by a sense of consciousness towards interests of others and as long as one's actions are not detrimental to another, it is acceptable. Such distinction and conditions are not observed in the transaction cost theory because the assumption here is that human behavior is based on self-interest with an element of craftiness, resulting in issues of moral hazard and adverse selection.

With regards to profit maximization, there is no evidence in primary sources such as the Holy Quran and Hadiths that puts a limit to profit [28]. In fact, there are evidences from Hadiths that the Prophet (s.a.w) allowed for profits up to 100 percent or even more. One such example involves one of the Prophet's companions

\footnotetext{
${ }^{3}$ Based on definition by Merriam-Webster dictionary

${ }^{4}$ Based on definition by Merriam-Webster dictionary
} 
who bought a piece of land in Madinah for 170,000 dinar and subsequently sold it for 1,600,000 dinar which is nine times more than its original price. Unfortunately, the profit maximization model adopted by many organizations (through transaction cost theory) suggests its main responsibility is towards capital providers.

Social welfare responsibilities, however, should be taken care by the government. Clearly, this does not adhere to principles outlined by Shari'ah as businesses have other obligations towards the community such as ensuring socio-economic justice via an equitable distribution of wealth.

\subsection{Political Theory: An Islamic Perceptive}

This section discusses the political theory from the Islamic aspect and thus it focuses on how Shari'ah views the role of the government as well as issues in relation to hostile takeovers and ownership. Governments are responsible for securing justice. Quoting St Augustine from the $5^{\text {th }}$ Century CE, "removed from justice, what be rulers if not large-scale robbers". According to Miller and Bersoff[29], justice is the constant and perpetual will to render to everyone his due. Aristotle himself sees demands of justice being met in a state ruled by a political constitution and impersonal laws [20]. Similarly, the Islamic political system's duty is to establish socio-economic justice as observed in the verses of the Holy Quran, 7:181 and 57:25 respectively;And among those We created is a community which guides by truth and thereby establishes justice. We have already sent Our messengers with clear evidences and sent down with them the Scripture and the balance that the people may maintain (their affairs) in justice.

The term politics (siyasah) has been used in the Prophet's Hadith where he said"The children of Israel used to be politically guided by their prophets but there is no prophet after me". Here 'politics' can be best defined as the "means to offer leadership and guidance to people towards the attainment of good both in this Life and the Hereafter" [30]. Contrary to this definition, the political theory does not take into account aspects of Hereafter. In addition, from time to time, the renowned Muslim scholars have emphasized on the role of the state. There are varying views on how far the state should go in fulfilling its role, as seen in the literature known as "Mirrors for Princes". Both al-Dimashqi and IbnKhaldun, however, strongly disapproved of the state becoming directly involved in the economy. According to IbnKhaldun, the state should not become "monolithic or despotic" and resort to "a high degree of regimentation" [31]. Instead, it should be more welfare-oriented, moderate in its spending, respect the property rights of citizens and avoid onerous taxation. From the definition provided, the political theory goes against principles outlined by the Muslim scholars because it suggests that governments should be directly involved.

As discussed before, different corporate governance systems in a conventional setting provide varying degrees of voting power and this can either accommodate hostile takeovers or otherwise. Before we can evaluate if the act is in line with Shari'ah, we need to consider if there actually exists 'friendly' acquisitions. Usually, a company only becomes a target for takeovers when it is extremely undervalued and there is serious inconsistency between its price and intrinsic value. This is a result of managerial decisions that are not made with the shareholders' interests. For example, the management, in their bid to manipulate market price, adopts a conservative dividend policy even though there are more than enough cash reserves to provide shareholders with their rightful share. In this case, hostile takeovers are necessary to replace a dishonest or incompetent management and thus it seems to be ethical from sharia's point of view.

There is a need for closer examination into the motivation behind acquiring other companies and implications of takeovers on various stakeholders. Managers of acquirer-companies desire to bring more assets under their control and run large business empires even if it is disadvantageous to shareholders in the longterm[31]. Moreover, hostile takeovers may have adverse effects on other stakeholders such as customers, employees and suppliers. A shift in control usually comes with extensive organizational change and existing employees. For instance, they may face repercussions such as job losses or low morale. In view of the motivations and implications of hostile takeovers, the political theory is not in line with principles of Shari'ah.

As confirmation that this model is not acceptable from an Islamic perspective, we reflect on the issue of ownership. Like other conventional theories of corporate governance, the political theory does not recognize the concept of absolute ownership that entitles the owner to act on his property without restriction or restraint. From an Islamic point of view, this type of ownership is only attributed to God as indicated in the Holy Quran, 53:31;And to Allah belongs whatever is in the heavens and whatever is in the earth.

\subsection{Resource Dependency Theory: An Islamic Perceptive}

In the context of corporate governance, the term resources relate to the board of directors particularly the board size and the board composition. There is no universal agreement on the optimum size of a board of director but typically a board with a large number of members can pose challenges in terms of its effectiveness and level of meaningful individual's participation.

With regard to the board composition, the resource dependency theory suggests that an organization can minimize uncertainty and manage dependence by way of inviting a representative of the source of constraint 
onto its governing board, thus exchanging sovereignty for support [12]. In other words, it refers to someone from outside the organization that holds some form of financial interest to be appointed as a member of the board i.e. the non-independent director. This theory seems to support the view of co-operation through mutual interdependence. This principle is recognized in Islam as it is part of the ethical virtues. The concept of cooperation is encouraged in Islam, since human being is interdependence each other. Furthermore, Allah commands the Muslim to work together and help one another. The importance of co-operation can be found in the Holy Quran, 5:2;Co-operate in good and piety and do not co-operate in sin and transgression. And fear Allah for Allah is strict in punishment.

Nevertheless when it comes to merger and acquisition the dominant firm may sometimes take advantage on the dependent firm's weaknesses. The former one may exploit the resources of the dependent firm. Islam prohibits from consuming one's wealth or property unjustly. This prohibition has been mentioned in several verses of the Holy Quran, 2:188 and 4:29 respectively;

And eat up not one another's property unjustly (in any illegal way e.g. stealing, robbing, deceiving, etc.), nor give bribery to the rulers (judges before presenting your cases) that you may knowingly eat up a part of the property of others sinfully.

O you who believe! Eat not up your property among yourselves unjustly except it be a trade amongst you, by mutual consent. And do not kill yourselves (nor kill one another). Surely, Allah is Most Merciful to you. These two verses state that we are not allowed to use other people goods or property without permission. Such action will violate and harm other's rights.

Overall, the resource dependency theory contradicts with Shari'ah rules because one party will take for granted on the other party resources for its own benefits. Even though the concept of this theory is based on mutual benefit that is parallel to Islam, in most occasions, there exists exploitation of resources. On the whole, this theory is not in favor in the light of Shari'ah.

\section{Conclusion}

Conventional corporate governance theories have been dominating the mindset of the regulators and corporate governance guidelines developers. Most of these theories assume that the human being is the rational decision makers and they will try to maximize their benefits. In addition, the religious teaching and spiritual aspect of human being are not considered in the corporate governance theories, for instance, transaction cost theory, political theory and resource dependency theory.This paper examines these theories from the Islamic perspective.The findings of this paper show that all these theories are not completely in line with Shari'ah. The main reason is they are self-interest motive and are lack of considering the ethical and social responsibility and fairness to all the involved parties.It is believed that this research opens the eyes of the regulators, industrial players and investors to recheck the suitability of these theories for the Islamic financial institutions.

\section{References}

[1] Abdussalam Mahmoud Abu-Tapanjeh, Corporate governance from the Islamic perspective: A comparative analysis with OECD principles, Critical Perspectives on Accounting (2009).

[2] Coase, R. H. The Nature of the Firm (2002).

[3] Badulescu, D., \&Badulescu, A. Theoretical Background of Corporate Governance (I), Annals of the Oradea University, Fascicle of Management and Technological, (2008).

[4] Williamson, O. E., The Mechanisms of Governance,(New York: Free Press, Macmillan1998),

[5] Williamson, O. E. The Economics of Organization: The Transaction Cost Approach. The American Journal of Sociology, 1981,548577

[6] Pound, J., The rise of the political model of corporate governance and corporate control. New York University Law Review, 68 (5),1993, 1003-71.

[7] Eckersley, Environmentalism and Political Theory: Toward an Ecocentric Approach (Suny Series in Environmental Public Policy 1992).

[8] Vives, X, "Banking and Regulation in Emerging Markets", The World Bank Research Observers, 21, 2, 2006, 179-206.

[9] Vives Xavier ed, Corporate Governance: Theoretical and Empirical Perspectives, (Cambridge: CUP, 2006.

[10] Roe, M.J. Political Determinants of Corporate Governance: Political Context, Corporate Impact. Oxford, (Oxford University Press, 2003).

[11] Davis, G. F., \& Cobb, J. A Resource Dependence Theory: Past and Future, Research in the Sociology of Organizations, (2009).

[12] Awotundun D. A., Kehinde J. S., \&Somoye R.O.C Corporate Governance and Stakeholders Interest: A Case of Nigerian Banks, International Journal of Business and Management, Vol. 6, No 10,2011.

[13] Van-Ness Raymond K, Miesing Paul, and Kang v, Understanding Governance and Corporate Boards: Is Theory A Problem? (2013).

[14] Pfeffer, J. "Merger as a response to organizational interdependence." Administrative Science Quarterly, 17,1972, 218-28.

[15] Pfeffer, J. "A resource dependence perspective on inter corporate relations." In M. S. Mizruchi and M. Schwartz (Eds.), Inter corporate Relations: The Structural Analysis of Business, 25-55, (Cambridge, UK: Cambridge University Press,1987).

[16] Anderson, Erin W. and Barton Weitz, "The Use of Pledges to Build and Sustain Commitment in Distribution Channels", Journal of Marketing Research, 29 (February), 18- 34, [1992].

[17] ZulkifliHasan, Corporate Governance: Western and Islamic Perspectives, International Review of Business Research Papers, Vol. 5, No. 1, 2009, 277-293. 
[18] Al-Attas, S.S, Islam and the Challenge of Modernity: Proceeding of the Inaugural Symposium on Islam and the Challenge of Modernity: Historical and Contemporary contexts, (Kuala Lumpur: The International Institute of Islamic Thought and Civilization, 1994).

[19] IqbalZafar\& Lewis, M. Lan, Islamic Perspective on Governance, (Edward, Elgar Publishing Limited, 2009.

[20] Abdul Rahim Abdul Rahman, Issue in Corporate Accountability and Governance: An Islamic Perspective, The American Journal of Islamic Social Science, Vol. 15, No. 1, 2010.

[21] ZulkifliHasan. Corporate governance in Islamic financial institutions: An Ethical Perspective. Prime Journals of Business Administration and Management (BAM) Vol. 2, No. 1, 2012, 405-411.

[22] Paino, Halil, Bahari, AAnis, B. and Abu Bakar, Rosliza. "Shariah, Social Responsibilities and Corporate Governance of the Islamic Banks in Malaysia", European Journal of Social Sciences, Volume 23, No. 3, 2011, 382-391.

[23] Khir, K., Gupta, L, Shanmugam B. Islamic Banking: A Practical Perspective. (Kuala Lumpur: Pearson Malaysia Sdn.Bhd, 2008).

[24] AyshaShafat Ahmed, An Examination of the Principles of Corporate Governance from an Islamic Perspective: Evidence from Pakistan, Arab Law Quarterly 25, 2011, 27-50.

[25] ShahulHameed Mohamed Ibrahim, The need for Islamic accounting: Perception of Malaysian Muslims accountants and academicians on the objectives and characteristics of Islamic accounting, unpublished PhD thesis. University of Dundee, UK, 2000.

[26] HasanZubair, Scarcity, Self-interest and Maximization from Islamic Angle. INCEIF the Global University in Islamic Finance,MPRA Paper No. 29414, 2011.

[27] MohdAzmi, O., Azman, M.N. \&AhamedKameel, M.M., an Islamic Pricing Benchmark (2010).

[28] Miller Joan G and Bersoff David M. Culture and Moral Judgment: How Are Conflicts Between Justice and Interpersonal Responsibilities Resolved? Journal of Personality and Social Psychology, Vol. 62, No. 4, 1992, 541-554.

[29] Tag el-Din, Seif I. and and M. Kabir Hassan "Islam and Speculation in the Stock Exchange," in Handbook in Islamic Banking, edited by M. Kabir Hassan and Mervyn K. Lewis, (Edward Elgar Publishing Company 2006).

[30] Chapra, M. U, Islamic Economics: What it is and How it Developed, (Islamic Research and Training Institute, 2010).

[31] Doytch Nadia, CakanEsin, Growth Effects of Mergers and Acquisitions: A Sector-level Study of OECD countries,Journal of Applied Economics and Business Research JAEBR, 1(3): 2011, 120-129. 